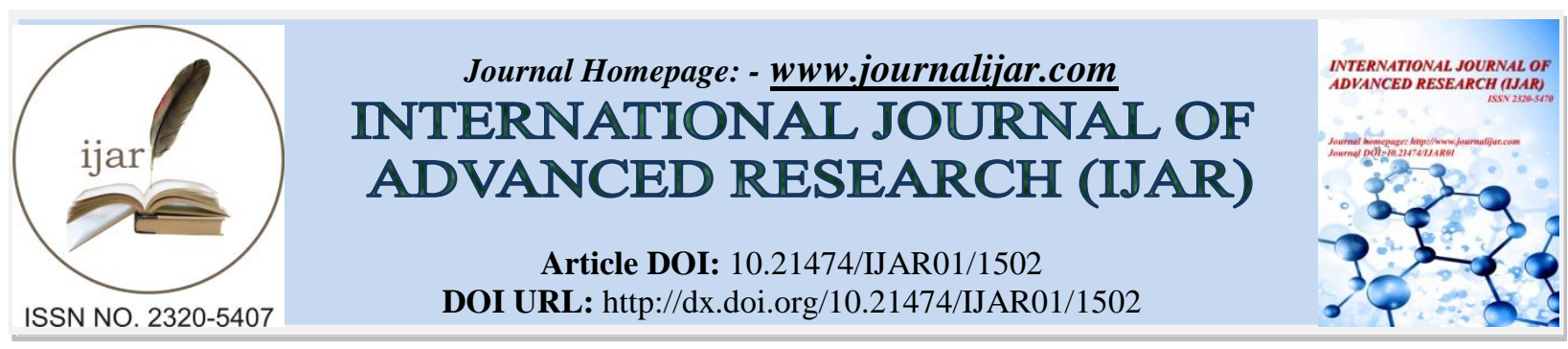

RESEARCH ARTICLE

\title{
STATUS OF SOIL PROPERTIES IN DIFFERENT BUFFER FORESTS OF MANAS BIOSPHERE RESERVE.
}

Arundhati Bezbarua ${ }^{1}$, Gajen Chandra Sarma ${ }^{2}$ and Sarbeshwar Kalita ${ }^{3}$.

1. Ph.D. Research Scholar, Department of Environmental Science, Gauhati University, Guwahati-14.

2. Curator, Department of Botany, Gauhati University, Guwahati-14.

3. Department of Environmental Science, Gauhati University, Guwahati-14.

\section{Manuscript Info}

Manuscript History

Received: 12 July 2016

Final Accepted: 19 August 2016

Published: September 2016

Key words:-

Soil properties, landuse, Manas

biosphere reserve

\section{Abstract}

The soil properties of the rich buffer forests of Manas Biosphere Reserve in Indo-Bhutan zone was degraded by continuous logging pressure. This study selected an important buffer zone comprising of reserve forests namely Daodhora, Batabari, Subankhata and Dihira proposed reserve forest. The study aimed to find the relationship between the soil properties and different forest vegetation including disturbed land. Soil samples were collected and analyzed along with information of logging pressure, canopy cover and height in each landuse areas. The nitrogen (0.007 to 0.45 percent) and organic matter ( 0.13 to 1.57 percent) contents in soil significantly increased in evergreen, semievergreen and mixed deciduous forest in comparison to disturbed scrubland, grassland and human habitation and agricultural areas. In the microhabitat condition, sand percentage significantly varied in between 37.2-71.4 percent in Daodhora, 34.569.2 percent for Batabari, 55.2-78.6 percent for Subankhata and 58.969.2 percent for Dihira proposed reserve forest. Highest percentage of average sand particles were observed in the Subankhata reserve forest due to presence of maximum logging pressure in diverse altitudes and drainage systems. The forest destruction in eastern buffer zone of Manas Biosphere Reserve resulted in conversion of evergreen, semievergreen and mixed deciduous forests to scrubs and grassland including agricultural land and human habitation. This disturbance had caused soil degradation in terms of decrease of organic matter content and nitrogen, accumulation of sandy particles in disturbed areas and posed a serious threat to the restoration of forests and rich biodiversity of Manas biosphere reserve.

Copy Right, IJAR, 2016,. All rights reserved.

\section{Introduction:-}

Natural forest cover was shrinking in different parts of the globe due to tremendous anthropogenic exploitation that resulted in decrease of soil fertility. The openness of forest due to human influence also changed the microclimate like soil properties, temperature and moisture content of the area. According to United Nations' Food and Agriculture Organization (FAO), world has been losing 7.3 million hectors of forest per year. A comparison between 1990 and 2005 revealed that the global forest cover having 4077 million hectors of areas in 1990 was 
reduced to 3952 million hectors in 2005 (FAO, 2006) and poses a serious threat to the soil composition. The relation between soil composition and forest community has been an important aspect for natural ecosystem. There has been a close relationship between the natural evolution of the vegetation and the development of the soil (Sharma et al., 2010). Recently works on phytosociology and soil-vegetation interrelationship in the different forest types of Garhwal Himalayan region was done by (Sharma et al., 2010). Ecologists (Sundarpandian and Swamy, 2004) investigated the soil organic matter dynamics and carbon balance in disturbed tropical forest ecosystem in Western Ghats. Nitrogen in soil can change the spatial and temporal dynamics of vegetation (Knap et al., 1999). The plant species influences the rate of nutrients cycle within an ecosystem through litter-quality feedbacks (Wedin and Tilman, 1996; Evans et al., 2001).The pattern of forest plant diversity is very much depended on the variation of altitude that linked diverse soil organic matter and NPK availability (Tomer and Tripathi, 2004). Impact of human activities on plant diversity and soil properties in Nokrek biosphere reserve, Meghalaya was well documented (Prabhu et al., 2004). The gradient of temperature and moisture in combination with different soil conditions and altitudinal changes results in a mosaic of different vegetation types (Hilbig, 1995). Disturbances and environmental variability do ultimately create niche opportunities by modifying resource availability or supply rates. In open forest, the level of NPK is responsible for spread of weed species (Ramakrisnan, 1991) Argemone maxicana. Natural vegetation of the Indian subcontinent (Saxena, 1991) has been subjected to dramatic alteration through human interference.

Himalayan forests play an important role in tempering the inclemency of the climate, in cooling and purifying the atmosphere, in protecting the soil, in holding the hill slopes in position and in buffering up huge reserves of soil nutrients (Sharma et al., 2010). Eastern Himalayan region is very significant in terms of rich biodiversity for which it is under the two global biodiversity hotspots namely Himalayas and Indo-Burma amongst the world's 34 biodiversity hotspot. The different alluvial soil with diverse topography and unique climatic condition has been played a key role in development of rich soil profile. It is also enriched by the litter deposition from diverse forest canopies found in evergreen, semievergreen and deciduous forests. The availability of the nutrient contents that specially impact the vegetation pattern in a particular landscape also depended on the canopy of the forest. With continued forest destruction in the foothills of Indo-Bhutan areas, there might be drastic change in the soil nutrient components in the areas. The reserve forests in the buffer of Manas biosphere reserve located in the Indo-Bhutan border areas have lost significant forest cover. The Manas biosphere reserve which serves as habitats of so many endangered and endemic flora and fauna has been facing excessive biotic pressure due to continuous political imbalance since 1987. Bezbarua (2008) pointed out that there was significant encroachment in the eastern buffer resulting fragmentation of the forests. The buffer forests of Manas biosphere was comprised of evergreen forest, semievergreen forests, mixed deciduous forest, degraded forests and degraded scrub forests as described by Bezbarua, (2012) including agricultural land and human habitation. Therefore the present study focused on the relation between forest community types and soil nutrient contents in the selected buffer forests of Manas biosphere reserve.

\section{Materials and methods:- Study Site:-}

Manas biosphere reserve is geographically located in between $89^{\circ} 51^{\prime} 45^{\prime \prime} \mathrm{E}$ to $92^{\circ} 07^{\prime} 00^{\prime \prime} \mathrm{E}$ and $26^{\circ} 30^{\prime} 00^{\prime \prime} \mathrm{N}$ to $26^{\circ} 56^{\prime} 43^{\prime \prime} \mathrm{N}$ covering a total area of $2837.12 \mathrm{sq}$. $\mathrm{km}$. The altitude of the biosphere reserve ranges between 58 meters to 720 meters from mean sea level. The topography is diverse in nature. The general appearance is of flat plain, yet undulating small hilly areas in the northern boundary, low-lying areas and some perennial and seasonal rivers and water bodies are the characteristic of the landscape. This study selected the major portion of eastern buffer $\left(91^{\circ} 13^{\prime} 00^{\prime \prime} \mathrm{E}\right.$ to $91^{\circ} 26^{\prime} 00^{\prime \prime} \mathrm{E}$ and $26^{\circ} 44^{\prime} 00^{\prime \prime} \mathrm{N}$ to $\left.26^{\circ} 50^{\prime} 15^{\prime \prime} \mathrm{N}\right)$ adjacent to core zone and comprised of different reserve forests (R.F.) namely Daodhora R.F.(17.48 sq.km.), Batabari R.F.(31.21 sq.km.), Subankhata R.F. (23.38 sq.km.), Dihira Proposed R.F. (7.80 sq.km.) under North Kamrup division. 
The climate of the biosphere reserve is subtropical in nature. The temperature ranges in between $6^{\circ}-37^{\circ}$ Celsius. Rainfall ranges between $3000 \mathrm{~mm}-4000 \mathrm{~mm}$ per year, attaining peak during July and August that caused flash flood for a short period. The coolest period is from late December to early January while hottest season is recorded in the month of May. The driest period of the season is in between late February to early March.

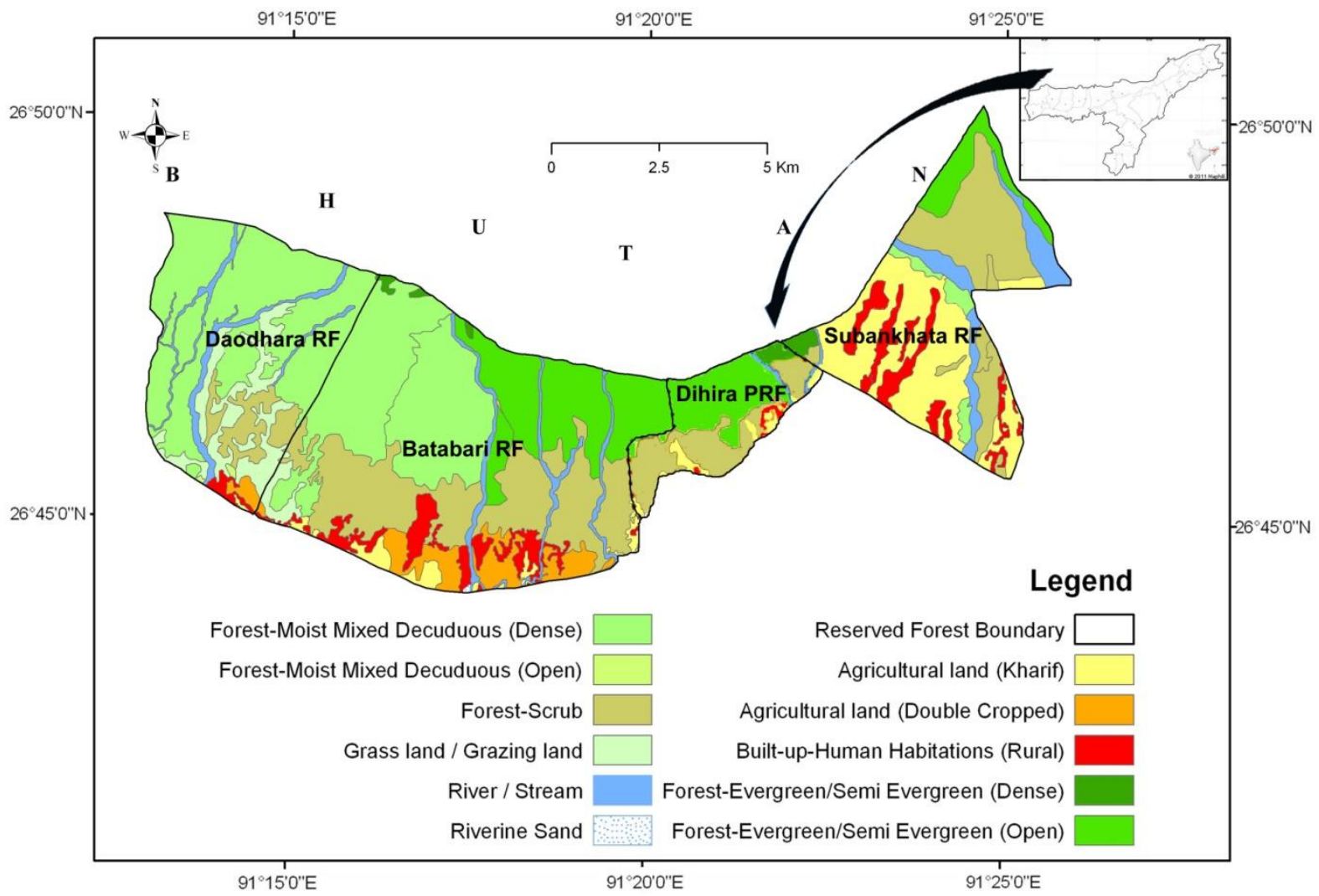

Fig. 1:- Map of the selected buffer forests of Manas Biosphere Reserve(study site).

\section{Methods:-}

Source:- Project Report of the Corresponding Author (Bezbarua, 2012).

Soil samples were collected in each forest type or landuse namely evergreen forest/semievergreen forest, mixed deciduous forest, scrub, grassland, agricultural land and human habitation. Different soil parameters like organic matter content, nitrogen, phosphorus, potassium, soil texture, soil moisture content were evaluated following standard soil testing laboratory method. Estimation of organic matter and nitrogen, phosphorus and potassium were done by the methods described by (Wakley and Black, 1934) and Jackson (1973) respectively. Total nitrogen was determined by using micro-Kjeldahl method, phosphorus by colorimetrically and potassium by flame photometer. Soil moisture, was estimated by method described by Sarma (1996).

Average canopy cover and canopy height of forests were also visually estimated in 10meterX10 meter quadrat as percentage and in meter respectively. Three quadrats were laid randomly and average values were considered.

Data on logging pressure was also estimated visually using 5 point scale like $1=$ race, $2=1-30 \%, 3=31-50 \%$, 4=51-75\%, $5=$ above $75 \%$ in each landuse.

Statistical analysis was carried out with support of software SPSS 9.0. Analysis of Variance (ANOVA) and Pearson Correlation were used to confirm significance of the result as well as finding relation between soil and forest types and landuses. 


\section{Results:-}

The average nitrogen and organic matter contents (Table1) of the soil significantly increased in evergreen/semievergreen forests and mixed deciduous forest in comparison to disturbed scrubland, grassland, human habitation and agricultural sites. Clear change of average canopy cover and height were also observed with change of the logging pressure intensity. ANOVA supported by Duncan post hoc test indirectly indicated the presence of moderate to heavy logging pressure in scrub forest, grassland and encroached land in comparison to evergreen/semievergreen forests. It resulted in significant (Table 2, Fig. 2, Fig.3, Fig. 4, Fig. 5) decrease of the soil organic matter and nitrogen due to presence low canopy cover and canopy height.

Interestingly, there was no significant difference between the average value of phosphorus, potassium contents including soil parameters like sand, silt, clay, moisture percentage value (Table 1) in the studied site of Manas biosphere reserve. But when ANOVA was performed considering undisturbed (evergreen/semievergreen and mixed deciduous forests) and disturbed land (scrub, grassland, human habitation and agricultural land), significant change in sand quality (Table 3), $\mathrm{pH}$, were observed apart from significant change of canopy cover, height, nitrogen and organic matter. The increase of sand was found in the disturbed sites (Fig.2, Fig.3, Fig.4, Fig. 5) when there was significant decrease of canopy cover, height, $\mathrm{pH}$, nitrogen and organic matter.

The result indicated that the soil texture (Fig. 2, Fig. 3, Fig. 4, Fig. 5) of the all the 3 reserve forests namely Daodhora, Batabari, Subankhata and Dihira proposed reserve forest were comprised of higher percentage of sand, low to moderate percent of clay and silt particles depending upon the different landuses located in various topographical (altitude) areas. The sand percentage ranged in between 37.2-71.4 percent in Daodhora, 34.5-69.2 percent for Batabari, 55.2-78.6 percent for Subankhata and 58.9-69.2 percent for Dihira proposed reserve forest. Interestingly highest sandy particles were observed in the grassland of the different reserve forests which turned to be highest in Subankhata RF. This may be due to the excess loss of the forest in the riparian vegetation with undulating altitudianl variation. The opening of the land having poor forest cover favour loss of binding capacity of the soil and resulted easy erosion causing more sandy nature of the habitats. The correlation between different soil properties indicated that sand showed significant negative correlation to clay (Table 4). This might be due to opening of the forest resulting excess deposition of the sand particle during rainy season in disturbed site or landuse with low altitude. The silt also showed significant negative correlation with potasium, while organic matter significantly changed the $\mathrm{pH}$ in the reserve. Silt percentage was changed with the disturbance of the forest while potassium stayed with clay particle and favoured by plants for its metabolic activity. In disturbed forest or undisturbed forest, potassium cycle has been involved through natural forest ecosytem or scrub weed vegetation but silts drained off to lower altitude in disturbed condition resulting negative corelation. The organic matter deposited due to decomposition of litter fall and dead vegetation changed the $\mathrm{H}$ ion resulting acidic soil in undisturbed forest and vise versa in disturbed area. Phosphorus and Potassium showed significant correlation in the overall biosphere reserve. May be with increase of the vegetation cover, both the components mixed with soil through respective cycles and gradually showed slow decrease with disturbance.

With the increase of the logging pressure by human, there was rapid change of the forest types. The canopy cover and height also negatively related indicating significance of the study. The logging pressure influenced significant increase of the sand through natural and human made drainage and streams during the heavy rain in all the reserve forests. The significant positive correlation (Table 4) between clay and canopy cover, canopy height and soil moisture proved the soil binding properties of the clay particle in undisturbed forests. It also favoured more nitrogen and organic matter availability and confirmed through significant postive correlation beween them in the same analysis. With good canopy cover, the canopy height was also found to increase in evergreen and mixed moist undisturbed forests as indicated positive correlation (Table 4) between them. 
Table 1:- Showing average value of different soil parameters and logging pressure in relation to different landuse in Manas biosphere reserve. Letters superscript indicated significant differences in between the landuses. Duncan post Hoc test was performed during ANOVA to know the level of change

\begin{tabular}{|c|c|c|c|c|c|c|c|c|c|c|c|c|}
\hline & 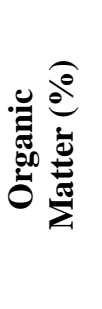 & 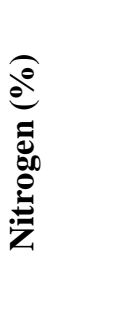 & 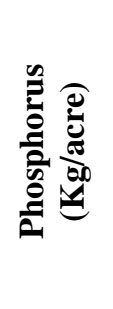 & 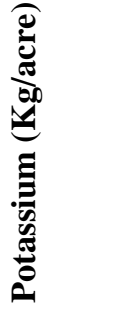 & 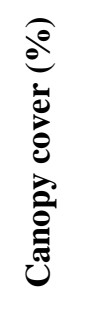 & 离 & 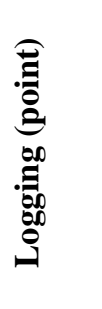 & $\frac{\pi}{2}$ & 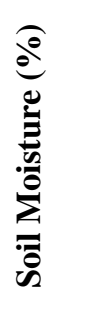 & 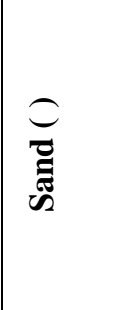 & 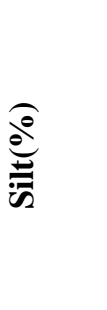 & $\underbrace{\frac{\partial}{0}}_{\frac{\vec{b}}{0}}$ \\
\hline $\begin{array}{l}\text { Evergreen/ } \\
\text { Semievergreen } \\
\text { Forest }\end{array}$ & $1.57^{\mathrm{a}}$ & $0.45^{x}$ & $0.58^{\mathrm{m}}$ & $37.2^{\mathrm{d}}$ & $48.75^{p}$ & $5.75^{\mathrm{e}}$ & $1^{r}$ & $4.01^{\mathrm{V}}$ & $16.12^{j}$ & $40.61^{\circ}$ & $15.04^{\mathrm{z}}$ & $19.33^{c}$ \\
\hline $\begin{array}{l}\text { Mixed } \\
\text { deciduous } \\
\text { Forest } \\
\end{array}$ & $1.67^{\mathrm{a}}$ & $0.44^{\mathrm{x}}$ & $0.51^{\mathrm{m}}$ & $38.55^{d}$ & $42^{p}$ & $4.5^{\mathrm{ef}}$ & $1.25^{\mathrm{rs}}$ & $4.03^{v}$ & $23.26^{j}$ & $32.69^{\circ}$ & $17.34^{\mathrm{z}}$ & $24.96^{c}$ \\
\hline $\begin{array}{l}\text { Barren land/ } \\
\text { scrub }\end{array}$ & $1.07^{\mathrm{ab}}$ & $0.01^{\mathrm{y}}$ & $0.895^{\mathrm{m}}$ & $52.97^{d}$ & $10.5^{\mathrm{q}}$ & $2.75^{\mathrm{ef}}$ & $2.75^{\mathrm{s}}$ & $5.89^{v}$ & $12.75^{j}$ & $59.03^{\circ}$ & $20.52^{z}$ & $20.43^{c}$ \\
\hline Grassland & $0.21^{b}$ & $0.004^{\mathrm{y}}$ & $0.898^{\mathrm{m}}$ & $52.65^{d}$ & $1^{\mathrm{q}}$ & $0.82^{f}$ & $2^{\mathrm{rst}}$ & $4.63^{v}$ & $22.16^{j}$ & $54.81^{\circ}$ & $9.81^{\mathrm{z}}$ & $10.37^{c}$ \\
\hline Agriculture & $0.29^{b}$ & $0.017^{y}$ & $0.44^{\mathrm{m}}$ & $46.94^{d}$ & $0^{\mathrm{q}}$ & $1^{f}$ & $3^{t}$ & $6.22^{v}$ & $13.75^{j}$ & $54.96^{\circ}$ & $20.26^{\mathrm{z}}$ & $24.77^{c}$ \\
\hline $\begin{array}{l}\text { Human } \\
\text { habitation } \\
\text { cum vegetable } \\
\text { garden }\end{array}$ & $0.13^{b}$ & $0.007^{\mathrm{y}}$ & $0.43^{\mathrm{m}}$ & $40.37^{d}$ & $0^{\mathrm{q}}$ & $1^{\mathrm{f}}$ & $3^{t}$ & $6.31^{\mathrm{v}}$ & $14.12^{\mathrm{j}}$ & $59.72^{\circ}$ & $24.11^{\mathrm{z}}$ & $16.15^{c}$ \\
\hline
\end{tabular}

Table 2 :- Analysis of varience (ANOVA) of different soil parameters, canopy cover, canopy height and logging pressure in relation to different landuse in Manas biosphere reserve.

\begin{tabular}{|c|c|c|c|}
\hline Parameters & df & F & Sig. \\
\hline Sand & 5,18 & 0.934 & 0.483 \\
\hline Clay & 5,18 & 1.098 & 0.396 \\
\hline Silt & 5,18 & 1.274 & 0.318 \\
\hline Organic matter & 5,18 & 3.322 & $\mathbf{0 . 0 2 7}$ \\
\hline Nitrogen & 5,18 & 6.038 & $\mathbf{0 . 0 0 2}$ \\
\hline Phosphorus & 5,18 & 1.169 & 0.362 \\
\hline Potassium & 5,18 & 0.445 & 0.811 \\
\hline Soil Moisture & 5,18 & 1.153 & 0.369 \\
\hline Canopy Cover & 5,16 & 1.025 & 0.436 \\
\hline Canopy Height & 5,18 & 6.104 & $\mathbf{0 . 0 0 2}$ \\
\hline Logging Pressure & 5,18 & 3.191 & $\mathbf{0 . 0 3 1}$ \\
\hline
\end{tabular}


Table 3 : Analysis of varience (ANOVA) of different soil parameters, canopy cover and canopy height in undisturbed (evergreen/semievergreen, decidous, forest) and disturbed (grassland, scrub forest, agricultural land, human habitation) landuse in Manas biosphere reserve.

\begin{tabular}{|c|c|c|c|}
\hline Parameters & df & F & Sig. \\
\hline Sand & 1,22 & 5.109 & $\mathbf{0 . 0 3 4}$ \\
\hline Clay & 1,22 & 0.827 & 0.373 \\
\hline Silt & 1,22 & 0.088 & 0.770 \\
\hline Organic Matter & 1,22 & 12.92 & $\mathbf{0 . 0 0 2}$ \\
\hline Nitrogen & 1,22 & 36.83 & $\mathbf{0 . 0 0 0}$ \\
\hline Phosphorus & 1,22 & 0.459 & 0.505 \\
\hline Potassium & 1,22 & 1.482 & 0.236 \\
\hline pH & 1,22 & 4.454 & 0.046 \\
\hline Soil Moisture & 1,20 & 1.093 & 0.308 \\
\hline Canopy Cover & 1,22 & 33.512 & $\mathbf{0 . 0 0 0}$ \\
\hline Canopy Height & 1,22 & 14.653 & $\mathbf{0 . 0 0 1}$ \\
\hline
\end{tabular}

Table 4:- Correlations between different soil parameters of the reserve forests under Manas Biosphere reserve. PC (Pearson Correlation).

\begin{tabular}{|c|c|c|c|c|c|c|c|c|}
\hline & & Clay & Silt & $\begin{array}{c}\text { Organic } \\
\text { Matter }\end{array}$ & Nitrogen & Phosphorus & Potassium & pH \\
\hline \multirow{3}{*}{$\begin{array}{l}\stackrel{\Xi}{\Xi} \\
\text { ڤ్ }\end{array}$} & $\mathrm{PC}$ & $-0.956 *$ & -0.872 & -0.636 & -0.567 & 0.835 & 0.877 & 0.729 \\
\hline & Sig. (2-tailed) & 0.011 & 0.054 & 0.248 & 0.319 & 0.078 & 0.051 & 0.162 \\
\hline & $\mathrm{N}$ & 5 & 5 & 5 & 5 & 5 & 5 & 5 \\
\hline \multirow{3}{*}{$\frac{\Xi}{U}$} & $\mathrm{PC}$ & & 0.690 & 0.799 & 0.655 & -0.681 & -0.725 & -0.875 \\
\hline & Sig. (2-tailed) & & 0.198 & 0.105 & 0.230 & 0.206 & 0.166 & 0.052 \\
\hline & $\mathrm{N}$ & & 5 & 5 & 5 & 5 & 5 & 5 \\
\hline \multirow{3}{*}{ 部 } & $\mathrm{PC}$ & & & 0.237 & 0.305 & $-0.925^{*}$ & $-0.954 *$ & -0.338 \\
\hline & Sig. (2-tailed) & & & 0.702 & 0.618 & 0.024 & 0.012 & 0.578 \\
\hline & $\mathrm{N}$ & & & 5 & 5 & 5 & 5 & 5 \\
\hline \multirow{3}{*}{ 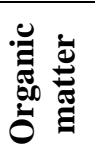 } & $\mathrm{PC}$ & & & & 0.768 & -0.286 & -0.340 & $-0.990 * *$ \\
\hline & Sig. (2-tailed) & & & & 0.130 & 0.641 & 0.576 & 0.001 \\
\hline & $\mathrm{N}$ & & & & 5 & 5 & 5 & 5 \\
\hline \multirow{3}{*}{ 总 } & $\overline{\mathrm{PC}}$ & & & & & -0.100 & -0.205 & -0.762 \\
\hline & Sig. (2-tailed) & & & & & .873 & .741 & .135 \\
\hline & $\mathrm{N}$ & & & & & 5 & 5 & 5 \\
\hline \multirow{3}{*}{ 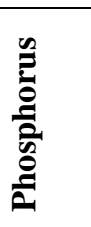 } & $\mathrm{PC}$ & & & & & & $0.993 * *$ & 0.380 \\
\hline & Sig. (2-tailed) & & & & & & 0.001 & 0.529 \\
\hline & $\mathrm{N}$ & & & & & & 5 & 5 \\
\hline \multirow{3}{*}{ 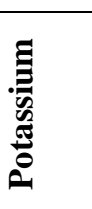 } & $\mathrm{PC}$ & & & & & & & 0.432 \\
\hline & Sig. (2-tailed) & & & & & & & 0.468 \\
\hline & $\mathrm{N}$ & & & & & & & 5 \\
\hline
\end{tabular}

* Correlation is significant at the 0.05 level (2-tailed)

** Correlation is significant at the 0.01 level (2-tailed). 


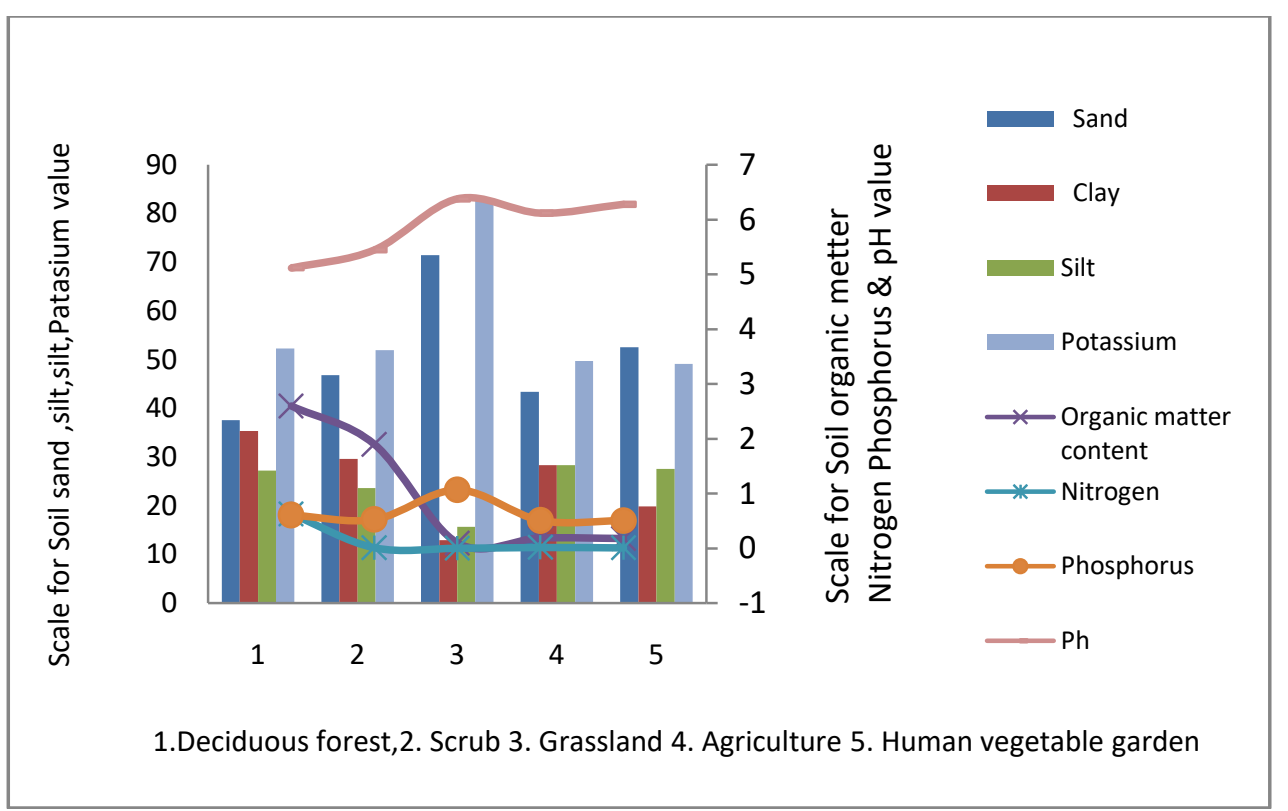

Fig. 2:- Soil Characteristics in different landuse of Daodhora R.F.

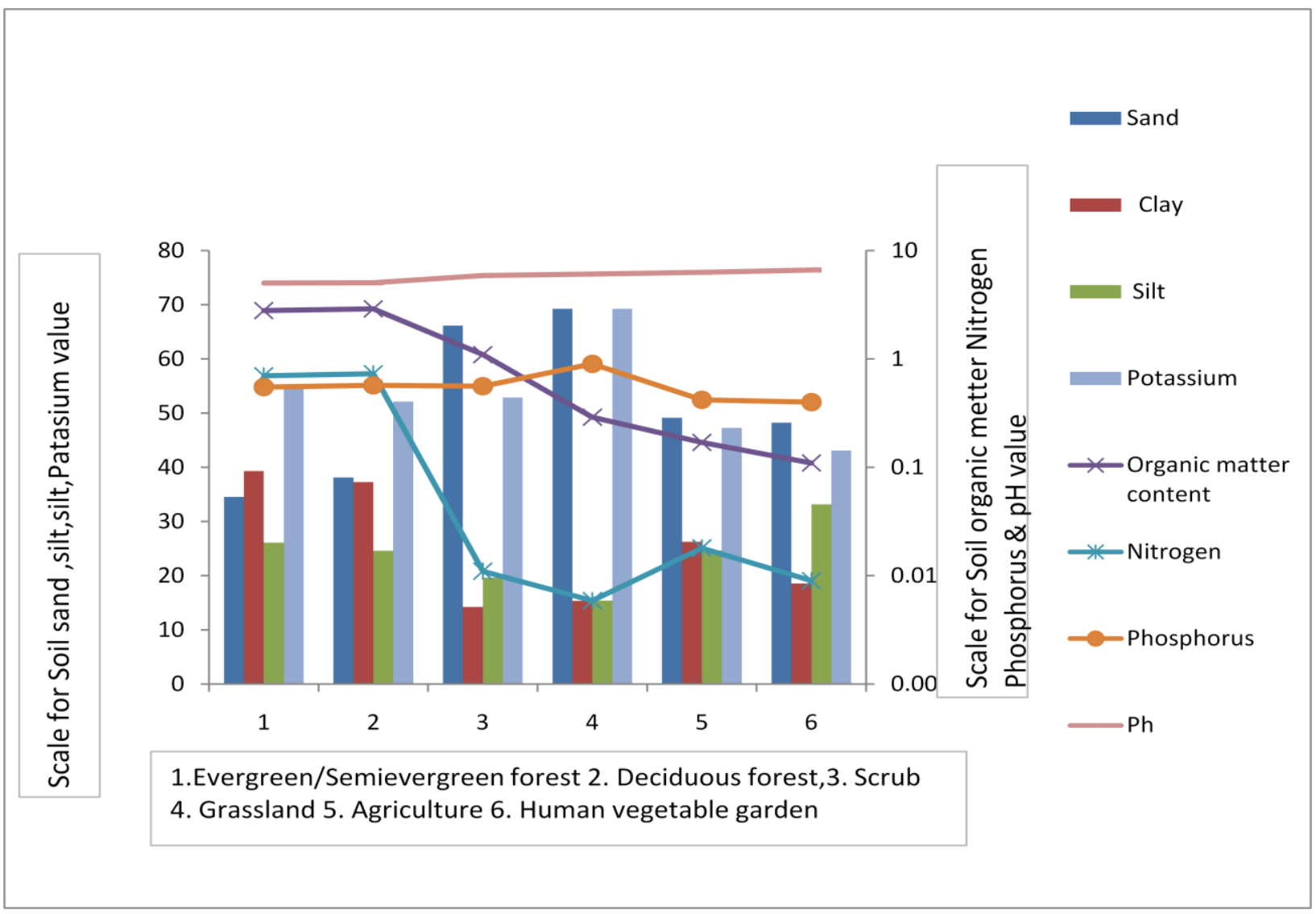

Fig. 3:- Soil Characteristics in different landuse of Batabari R.F. 




Log scale used in the right side to show the value lower than 1

Fig.4:- Soil Characteristics in different landuse of Subankhata R.F.

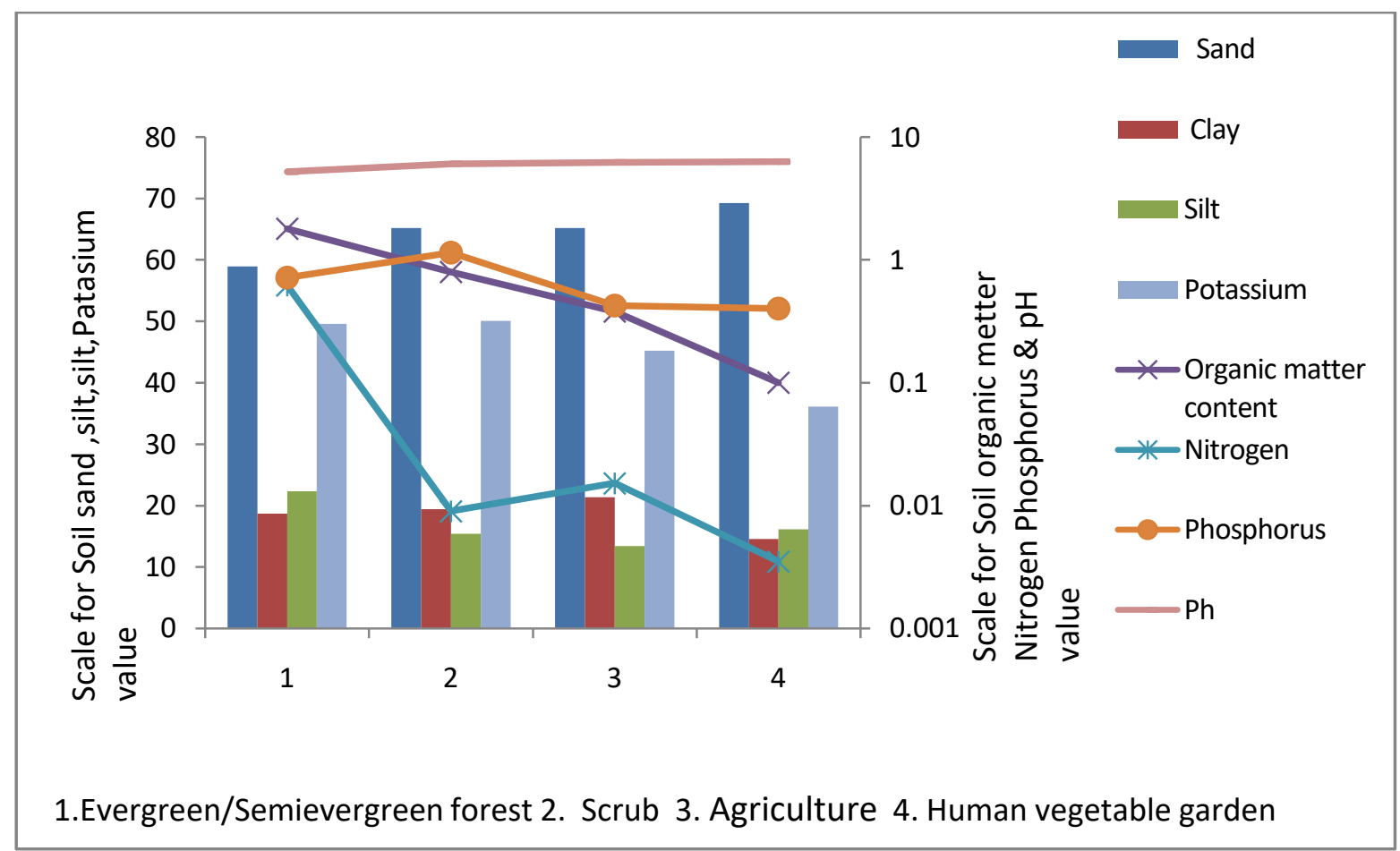

Log scale used in the right side to show the value lower than 1

Fig. 5:- Soil Characteristics in different landuse of Dihira P.R.F.

\section{Discussion:-}

It was observed that in the undisturbed forests like evergreen/ semievergreen forests, there was an increase of the soil organic matter and nitrogen content, while both the components decreased in open scrub, grassland or agricultural land and human habitation area created by logging pressure. This might be due to the accumulation and 
decomposition of litter contents available in undisturbed forests. Increased nitrogen content in soil under undisturbed condition depicts high rate of litter decomposition while the decomposition rate is more rapid on nitrogen rich site (Gosz, 1981; Vitousek et al., 1994 and Prescott, 1995). But, the nutrient supply to the soil due to decomposition of litter is reduced with increase degree of disturbance (Conn and Dighton, 2000 and Zimmer, 2002). Researchers (Sundarpandian and Swamy, 2004) found similar findings where the soil organic matter decreased in disturbed tropical forest ecosystem in Western Ghats. The low availability of nitrogen and organic matter might influence the vegetation dynamics of the study sites with invasion of new species using the microclimate of increased moisture, temperature as well as available soil nutrients. (Knap et al., 1999) also observed the influence of nitrogen in soil that changed the spatial and temporal dynamics of vegetation types. The vegetation of different plant species influences the rate of nutrients cycle within an ecosystem through litter-quality feedbacks (Wedin and Tilman, 1996; Evans et al., 2001).

No significant change of the average soil texture like sand, silt and clay in the Manas biosphere reserve might be due to the diverse soil dynamics in relation to forest community structure that still had some good forest with natural self restoration capacity. Moreover the rainfall and different natural and human made channels might affect the distribution of the soil minerals. The undulating forest and grassland patches, grazing of the wildlife and domestic cattle in the forest might also influence overall similar properties of the soil. The pattern of distribution of forest plant diversity and types are very much depended on the variation of altitude that linked diverse soil nutrient availability (Tomer and Tripathi, 2004).

The correlation of the soil texture and available nitrogen, phosphorus and potassium including mositure content were seen with the change of the canopy cover, canopy height and logging pressure by the fringe villagers. Impact of human activities on plant diversity and soil properties was confirmed (Prabhu et al., 2004) in Nokrek biosphere reserve, Meghalaya. With open forest, the heliophytes replaced the schiophytes with increased sun lights and temperature. The gradient of temperature and moisture in combination with different soil conditions and altitudinal changes results in a mosaic of different vegetation types (Hilbig, 1995).

The significant increase of sand in the disturbed sites in all the reserve forests and proposed reserve forest suggested the microclimate variation of soil properties with decrease of the canopy cover and height. The change of the potasium and phosphorus seems to be slow as indicated by their postive correlation mentioned earlier. While nitrogen and organic matter was low in disturbed forests, the sharp decrease of nitrogen could be observed in the Subankhata and Dihira areas. This was due to the excessive opening of the forest by human activities in the Subankhata RF and Dihira PRF. The high slopping and altitude of the disturbed Subankhata RF in comparison to Daodhora RF and Batabari RF also favoured high speed of the water current and carrying of the large amount of sand particle to the low lying areas.

\section{Conclusion:-}

The average nitrogen and organic matter contents significantly increased in evergreen, semievergreen and mixed deciduous forest in comparison to disturbed scrubland, grassland and human habitation and agricultural sites. There was no significant change of the average phosphorus, potassium contents and soil properties like sand, silt, clay, moisture percentage value if considered overall landscape of buffer areas of Manas biosphere reserve despite human disturbance. This might be due to the diverse soil dynamics in relation to forest community structure that still has some good forests and self sustaining mechanism. However a detail study in the microhabitat level confirmed that the soil texture of the all the three reserve forests namely Daodhora, Batabari, Subankhata and Dihira proposed reserve forest were comprised of higher percentage of sand in disturbed areas. Highest sandy particles were observed in the Subankhata RF due to presence of maximum logging pressure and altitudinal variation and well developed drainage system.

The human impact on the forest destruction in eastern buffer forests of Manas Biosphere Reserve leads to the opening of canopy cover of the diverse forest types namely evergreen, semievergreen forest including mixed decidous forest and influenced the soil degradation in terms of decrease of organic matter content, nitrogen as well as accumulation of sandy particle in disturbed forests. The sandy nature of the disturbed forests are the result of well developed drainage system and poor vegetation cover to accelerate the soil erosion. The change in soil dynamic also leads to the poor growth of the forests in disturbed sites. 


\section{Acknowledgement:-}

The research work was supported by a Minor Research Project Grant from University Grant Commission (UGC) North East India branch, Guwahati. We would like to thank the local forest authority, local NGOs and villagers for the support during the field work. We are also thankful to the authority of Barama college, Botany and Environmental department of Gauhati University for extending necessary infrastructural facility during the study period.

\section{References:-}

1. Bezbarua, A. (2012): Study of vegetation type in buffer zone of Manas biosphere reserve. Unpublished final technical report for UGC, North East Regional Office, Guwahati, Barama College, Barama, India.

2. Bezbarua, P. (2008): Habitat evaluation and conservation of capped langur in Manas biosphere reserve. Unpublished final report for Primate Society of Great Britain, Grasshopper, India.

3. Conn, C. and Dighton, J. (2000): Litter quality influences on decomposition, ectomycorrhizal community structure and mycorrhizal root surface acid phosphatage activity. Soil Biology and Biochemistry. 32: 489-496.

4. Evans, R. D., Rimer, R., Sperry, L. and Belnap, J. (2001): Exotic plant invasion alters nitrogen dynamics in arid grassland. Ecological Applications 11: 1301-1310.

5. FAO, (2006): Statistical database of Food and Agricultural Organization of United Nations, Rome. Available online at: http.//apps.fao.org.

6. Gairola, S. (2010) Phytodiversity, forest composition, growing stock variation and regeneration status in the Mandal-Chopta forest of Garhwal Himalaya. D.Phil. Thesis, HNB Garhwal Central University, Srinagar (Garhwal), Uttarakhand, India.

7. Gosz, J.R. (1981): Nitrogen cycling in coniferous ecosystems. In: Clark, FE Rosswall (edition), Terrestrial nitrogen cycles. Ecology Bulletin (Stockholm) 33: 405-426.

8. Hilbig, W. (1995): The vegetation of Mongolia. SPB Academic Publishing, Amsterdam. Ecography, 24: 381-392.

9. Jackson, M. L. (1973): Soil Chemical Analysis. Prentice-Hall of India Private. Limited, New Delhi.

10. Knapp, A. K., Blair, J. M., Briggs, J. M., Collins, S. L., Hartnett, D. C., Johnson, L. C. and Towne, E. G. (1999): The Keystone Role of Bison in North American Tallgrass Prairie. Bioscience 49 (1): 39-50.

11. Prabhu, S.D., Ralte, V., Tripathi, R.S., Pandey, H.N. and Barik, S.K. (2004): Impact of human activities on plant diversity and soil properties in Nokrek biosphere reserve, Meghalaya. In: Shankar, U. (ed) International symposium on recent trends in plant ecology and biodiversity research, Abstract in a international symposium in NEHU, Shillong. Pp. 117.

12. Ramakrishnan P.S. (1991): Biological invasion in the tropics: an overview. In Ramakrishnan P.S. (ed). Ecology of Biological Invasion in tropics. pp 1-19 International Scientific Publications, India.

13. Sarma, P. D. (1996): Ecology and Environment. Rastogi Publications, Meerut.

14. Sharma, C.M., Baduni, N.P., Gairola, S., Ghildiyal, S.K. and Suyal, S (2010): The effect of slope aspects on forest compositions, community structures and soil properties in natural temperate forests in Garhwal Himalaya. J. For. Res. 21(3): 331-337.

15. Saxena K.G. (1991): Biological invasions in the Indian subcontinent: Review of invasion by plants. In Ramakrishnan P.S. (ed). Ecology of Biological Invasion in tropics. pp. 53-73 International Scientific Publications, India.

16. Sundarpandian, S.M. and Swamy, P.S. (2004): Organic matter dynamics and carbon balance in a tropical forest ecosystem at Kodayar in Western Ghats, India. In: Shankar, U. (ed) International symposium on recent trends in plant ecology and biodiversity research, Abstract in a international symposium in NEHU, Shillong. pp. 40

17. Tomar, J. M. S. and Tripathi O.P. (2004): Plant diversity in pine forests of Meghalaya, north east India. In: Shankar, U. (ed) International symposium on recent trends in plant ecology and biodiversity research, Abstract in a international symposium in NEHU, Shillong. pp. 99

18. Walkley, L. and Black, C.A. (1934): Determination of organic carbon. Soil Science. 37: pp. 29

19. Wedin D.A. and Tilman, D. (1996): Influence of nitrogen loading and species composition on the carbon balance of grasslands. Science. 274: 1720-1723.

20. Vitousek, P.M., Turner D.R., Parton W.J. and Sanford R.L. (1994): Litter decomposition on the Mauna Loa environmental matrix, Hawin patterns, mechanisms, and models. Ecology 75 418-429.

21. Zimmer M. (2002): Is decomposition of woodland leaf litter influenced by its species richness? Soil Biology and Biochemistry 34: 277-284. 